\title{
sciendo
}

\section{FENNEL AND GINGER IMPROVED NUTRIENT DIGESTIBILITY AND MILK YIELD AND QUALITY IN EARLY LACTATING EGYPTIAN BUFFALOES}

\author{
Nadia H. Fahim ${ }^{1}$, Ahmed E. Kholif ${ }^{\star}$, Hossam H. Azzaz ${ }^{2}$
}

\author{
${ }^{1}$ Animal Production Department, Faculty of Agriculture, Cairo University, Giza, Egypt \\ ${ }^{2}$ Dairy Science Department, National Research Centre, 33 Bohouth St. Dokki, Giza, Egypt \\ 'Corresponding author: ae_kholif@live.com, ae.kholif@nrc.sci.eg
}

\begin{abstract}
The supplementation with herbal and medicinal plants to animals showed positive effects on feed digestion, performance and animal's health. Fifteen multiparous Egyptian buffaloes (537 $\pm 18.1 \mathrm{~kg}$ body weight), 7 days after parturition, were randomly assigned to 3 treatments in a quintupled $3 \times 3$ Latin square design in a 63-day experiment. Each experimental period lasted 21 days (15 days of adaptation +7 days for measurements and samples collection). Buffaloes were assigned according to their previous milk production, weight and parity to study the effect of fennel (Foeniculum vulgare) or ginger (Zingiber officinale) supplementation on feed utilization and lactational performance. Buffaloes were fed a basal diet of concentrates, berseem clover and rice straw in a ratio of 60:30:10 dry matter (DM) basis. The first group was fed the basal diet with no additive as the control treatment, while other buffaloes were fed on the basal diet supplemented with $75 \mathrm{~g}$ fennel or ginger/buffalo daily. Additives supplementation did not affect feed intake; however, fennel followed by ginger improved $(P<0.05)$ dry matter, organic matter, crude protein and neutral detergent fiber digestibilities compared to the control. Without affecting blood chemistry, fennel and ginger supplementation improved $(\mathrm{P}<0.05)$ production of milk and energy corrected milk, fat concentration and milk energy content and output. Fennel followed by ginger decreased the somatic cell count $(\mathrm{P}=\mathbf{0 . 0 3 5})$ compared with the control. Fennel and ginger improved feed efficiency $(\mathrm{P}<\mathbf{0 . 0 5})$ compared with the control. Fennel increased the proportion of milk trans-10, cis-12 C18:2 $(\mathrm{P}=\mathbf{0 . 0 2 8})$, total conjugated linoleic acid without affecting other fatty acids. It is concluded that fennel or ginger at $\mathbf{7 5} \mathrm{g} / \mathrm{buffalo} / \mathrm{d}$ improved nutrient digestibility and milk production of lactating buffaloes. Fennel improved milk nutritive value more than ginger.
\end{abstract}

Key words: feed utilization, fennel, ginger, ionophores, milk fatty acids, milk production

For many years, herbal and medicinal plants feed additives have been used to stimulate appetite and digestion in ruminants and keep animal's health (Cedillo et al., 2015; Salem et al., 2017). Moreover, phytogenic compounds have been used in lieu of performance promoters (i.e., antibiotic ionophores) (Matloup et al., 2017; Khattab 
et al., 2020). Phytogenic additives include, for example, essential oils, herbs or seeds (Abd El Tawab et al., 2020).

Fennel (Foeniculum vulgare) is a plant belonging to the family Apiaceae (Dhayalan et al., 2015). The main phytoconstituents in fennel are anethole, limonene, $\alpha$-pinene, fenchol, fenchone and estragole (Hajalizadeh et al., 2019). Such compounds give fennel strong pharmacological activities, including antibacterial, antioxidant, and hepatoprotective activities (Kooti et al., 2015; Ghazy et al., 2021). Saeedi et al. (2017) stated that supplementing the starter diet of Holstein dairy calves with fennel for 2 weeks improved their growth and decreased the weaning age. Furthermore, Hajalizadeh et al. (2019) observed that feeding growing lambs for 80 days on diet supplemented with fennel at $1.5 \%$ of diet increased feed intake, feed conversion, final body weight and live weight gain.

Ginger (Zingiber officinale) is a plant belonging to the family Zingiberacae, with a long history of medicinal use in human due to its biological active compounds. Ginger contains volatile oil that can affect ruminal fermentation and feed digestion (Zhang et al., 2011). Al-Musodi and Jaafar (2019) evaluated the supplementation of ginger to lactating Iraqi goats at $60 \mathrm{~g} / \mathrm{kg}$ of concentrate diet for 5 months, and observed increased milk yield and milk contents of solids not fat, protein and lactose.

Limited data are available on the effect of ginger and fennel on lactational performance of lactating buffaloes. We hypothesized that feeding fennel or ginger would improve nutrient digestion, resulting in enhanced lactational performance of buffaloes. Therefore, the objective of the present experiment was to compare the effects of fennel or ginger on feed utilization, milk production, milk composition and milk somatic cell count (SCC) of in early lactation Egyptian buffaloes.

\section{Material and methods}

\section{Study location}

The experiment was carried out at the Agriculture Experimental and Research Station, Faculty of Agriculture, Cairo University (Egypt). The farm was located at latitude $30^{\circ} 01^{\prime} 47.6^{\prime \prime} \mathrm{N}$ and longitude $31^{\circ} 11^{\prime} 42.5^{\prime \prime} \mathrm{E}$. The analyses were performed at the laboratory of dairy animal production, National Research Centre (Egypt). Buffaloes were managed in accordance with the Guide for the Care and Use of Agricultural Animals in Agricultural Research and Teaching, 3rd edition, 2010 (Federation of Animal Science Societies, Champaign, IL, USA).

\section{Buffaloes and management}

During the first week of lactation, fifteen lactating Egyptian buffaloes $(537 \pm 18.1 \mathrm{~kg}$ body weight, $4 \pm 1$ parity, $7 \pm 1$ days in milk, previous milk production $7.8 \pm 0.1 \mathrm{~kg} / \mathrm{d}$ ) were assigned randomly to one of three experimental treatments in a quintupled $3 \times 3$ Latin square design, with three treatments, three periods, and 5 buffaloes per treatment within each period (resulting in 15 replicates per treatment for the whole experiment) for 63 days. Each experimental period lasted 21 days: 15 days of adap- 
tation to the new additive +7 days for measurements (feed intake, milk yield) and samples collection (sampling of feed and orts, feces, blood, milk).

Buffaloes were divided into three barns in soil-surfaced free stalls $(122 \times 175$ $\mathrm{cm}^{2} /$ buffalo), under shade, without any bedding and with free access to water. Buffaloes were ad libitum fed a diet containing (per $\mathrm{kg}$ dry matter (DM)) $600 \mathrm{~g}$ of concentrate feed mixture, $300 \mathrm{~g}$ of Egyptian berseem clover (Trifolium alexandrinum), and $100 \mathrm{~g}$ of rice straw (Oryza sativa) to meet their nutrient requirements according to NRC (2001) recommendations. Adjustments were made to the diets to ensure collection of orts. The nutrient contents of feed ingredients and basal diet are shown in Table 1. Individual buffaloes were weighed monthly on a multi-purpose platform scale.

Table 1. Composition of ingredients and experimental basal diet fed to the Egyptian buffaloes (g/kg DM basis)

\begin{tabular}{lcc|c|c}
\hline & $\begin{array}{c}\text { Concentrate } \\
\text { feed mixture }\end{array}$ & Berseem clover & Rice straw & Basal diet $^{1}$ \\
\hline Dry matter & 903.2 & 890.1 & 928.5 & 901.8 \\
Organic matter & 922.9 & 884.4 & 853.5 & 904.4 \\
Crude protein & 165.0 & 128.3 & 20.1 & 139.5 \\
Ether extract & 46.8 & 54.4 & 13.0 & 45.7 \\
Non-structural carbohydrates & 414.0 & 224.2 & 121.3 & 327.8 \\
Neutral detergent fiber & 297.1 & 477.5 & 699.1 & 391.4 \\
Acid detergent fiber & 175.1 & 380.7 & 458.0 & 265.1
\end{tabular}
basis.

${ }^{1}$ The control diet consisted of concentrates feed mixture, berseem clover and rice straw at 60:30:10 on DM

Buffaloes were fed their diets without any additives (control treatment) or supplemented with fennel or ginger at $75 \mathrm{~g} /$ buffalo daily. Dried, food grade, fennel and ginger obtained from a local supplier in Egypt were used. Diets were offered twice a day at 08:00 and 16:00 h. The additives were mixed with concentrate portion to individual buffaloes, once daily, before the morning feeding at 08:00 $\mathrm{h}$ to ensure the full dose was received. Fennel or ginger has been administered more than the daily diet. Buffaloes were offered the portion of concentrate feed mixture, followed by berseem clover and then rice straw. Samples of berseem clover, concentrate mixture and rice straw were taken daily, composited weekly, dried at $60^{\circ} \mathrm{C}$ in a forced-air oven for 48 h (method 930.15) (AOAC, 1997) and stored for chemical analyses.

\section{Feed intake and nutrient digestibility}

During the collection periods, feed intake was recorded daily by weighing the offered diets and refusals from the previous day. During the last week of each period (7 days), a nutrient digestibility trial was carried out in which acid insoluble ash was used as an internal indigestibility marker, and coefficients of digestion were calcu- 
lated according to Ferret et al. (1999). Fecal grab samples were collected from all buffaloes twice daily at 07:00 and 15:00 h, dried at $60^{\circ} \mathrm{C}$ in a forced-air oven for 48 $\mathrm{h}$ and pooled by buffalo.

Dried feed, orts and fecal samples were ground to pass a 1-mm screen and analyzed for DM (method 930.15), ash (method 942.05), nitrogen (method 954.01) and ether extract (EE; method 920.39) according to AOAC (1997) official methods. Neutral detergent fiber (NDF) was determined by the procedure of Van Soest et al. (1991) with the use of an alpha amylase and sodium sulfite and expressed exclusive of residual ash. Acid detergent fiber (ADF) was analyzed according to AOAC (1997) (method 973.18) and expressed exclusive of residual ash. Concentrations $(\mathrm{g} / \mathrm{kg} \mathrm{DM})$ of non-structural carbohydrates $(\mathrm{NSC})=1000-(\mathrm{NDF}+$ crude protein $(\mathrm{CP})+\mathrm{EE}+\mathrm{ash})$, and organic matter $(\mathrm{OM}=1000-\mathrm{ash})$ were calculated.

\section{Sampling and analysis of blood serum}

On the last day of each experimental period, $10 \mathrm{~mL}$ of blood samples were taken $4 \mathrm{~h}$ after feeding from the jugular vein of all buffaloes into a clean dry tube without anticoagulants. Blood samples were centrifuged at $4,000 \times g$ for $20 \mathrm{~min}$ at $14^{\circ} \mathrm{C}$. Serum was separated into 2-mL Eppendorf tubes and frozen at $-20^{\circ} \mathrm{C}$ until analysis. By using specific kits (Stanbio Laboratory, Boerne, Texas, USA) and following manufacturer instructions, blood serum samples were analyzed for concentrations of total protein, albumin, urea-N, glutamate-oxaloacetate transaminase (GOT), glutamatepyruvate transaminase (GPT), glucose, and cholesterol. Globulin concentration was calculated by subtracting albumin values from their corresponding total protein values.

\section{Milk sampling, and milk composition}

During sample period of each experimental period ( 7 days), buffaloes were machine milked twice daily at 09:00 and 21:00 h, and samples $(100 \mathrm{~g} / \mathrm{kg}$ of recorded milk yield) were collected at each milking. A mixed sample of milk (proportional to amounts produced in the morning and evening) was taken daily. Milk samples were analyzed for total solids, solids not fat, fat, protein, lactose and ash using infrared spectrophotometry (Milkotester LM2, Belovo, Bulgaria).

The gross energy content in milk was calculated according to Tyrrell and Reid (1965). The milk energy output $(\mathrm{MJ} / \mathrm{d})$ was then calculated as milk energy $(\mathrm{MJ} / \mathrm{kg}) \times$ milk yield (kg/d). Energy-corrected milk (ECM) was calculated according to Sjaunja et al. (1991).

Milk was freshly analyzed for SCC using NucleoCounter SCC instrument (ChemoMetec, Allerod, Denmark) based on ChemoMetec's proven technology of fluorescence image cytometry.

\section{Statistical analyses}

The Shapiro-Wilk test was used to test the normal distribution of variables. For the small number of variables that showed significance for the Shapiro-Wilk test, data transformation (i.e., natural $\log$ ) was applied before reanalyzing the normality 
of the residuals. Data were analyzed using a quintupled $3 \times 3$ Latin square design, with three periods and three treatments. Individual buffaloes were the experimental units. Data for variables measured daily for each week were averaged before statistical analyses. The statistical model included the fixed effect of square and treatment and the random effects of period and buffalo nested within square:

$$
Y_{i j k l}=m+S_{i}+T_{j}+P_{k}+B_{l}\left(S_{i}\right)+E_{i j k l}
$$

where $Y_{i j k l}$ is each individual observation for a given variable, $m$ is the overall mean, $S_{i}$ is the square effect, $T_{j}$ is the treatment effect, $P_{k}$ is the period effect, $B_{l}\left(S_{i}\right)$ is the effect of buffalo within square, and $E_{i j k l}$ is the residual error. Statistical analyses were performed using PROC MIXED of SAS Version 9.4 (SAS Inst., Inc., Cary, NC, 2020). The probability of difference option of the least squares means statement was used for multiple comparisons of means. In addition, means also were compared using orthogonal contrasts (i.e., control vs. the average of fennel and ginger; and fennel vs. ginger).

\section{Results}

\section{Feed intake, digestibility and blood measurements}

Fennel or ginger supplementation did not affect feed intake (Table 2). Fennel followed by ginger improved digestibility of $\mathrm{DM}(\mathrm{P}=0.001), \mathrm{OM}(\mathrm{P}=0.002), \mathrm{CP}$ $(\mathrm{P}=0.003)$ and NDF $(\mathrm{P}=0.025)$ compared with the control with greater NSC digestibility $(\mathrm{P}=0.025)$ and digestible $\mathrm{CP}(\mathrm{P}=0.003)$ for fennel compared with the control.

Additives supplementation did not affect the concentrations of serum total proteins, albumin, globulin, urea-N, glucose, GPT, GOT or cholesterol (Table 2).

\section{Lactational performance}

Fennel and ginger improved production of milk $(\mathrm{P}=0.007), \mathrm{ECM}(\mathrm{P}=0.021)$ and milk energy output $(\mathrm{P}=0.039)$ (Table 3$)$. Moreover, fennel and ginger supplementation showed greater milk fat concentration $(\mathrm{P}=0.03)$ and milk energy content $(\mathrm{P}=0.028)$ compared with the control. Fennel followed by ginger decreased $(\mathrm{P}=0.035)$ the SCC compared with the control. Both fennel and ginger improved feed efficiency calculated as milk/feed intake $(\mathrm{P}=0.034)$ or $\mathrm{ECM} /$ feed intake $(\mathrm{P}=0.036)$ compared with the control.

Fennel and ginger showed greater proportions of cis-9, trans-11 C18:2 ( $\mathrm{P}=0.032)$, while fennel improved the proportion of trans-10, cis-12 $\mathrm{C} 18: 2(\mathrm{P}=0.028)$, total conjugated linoleic acid (CLA) $(\mathrm{P}=0.031)$ and omega-6/omega-3 ratio $(\mathrm{P}=0.02)$; however, decreased $(\mathrm{P}=0.01)$ polyunsaturated fatty acids (PUFA) (Table 4). 


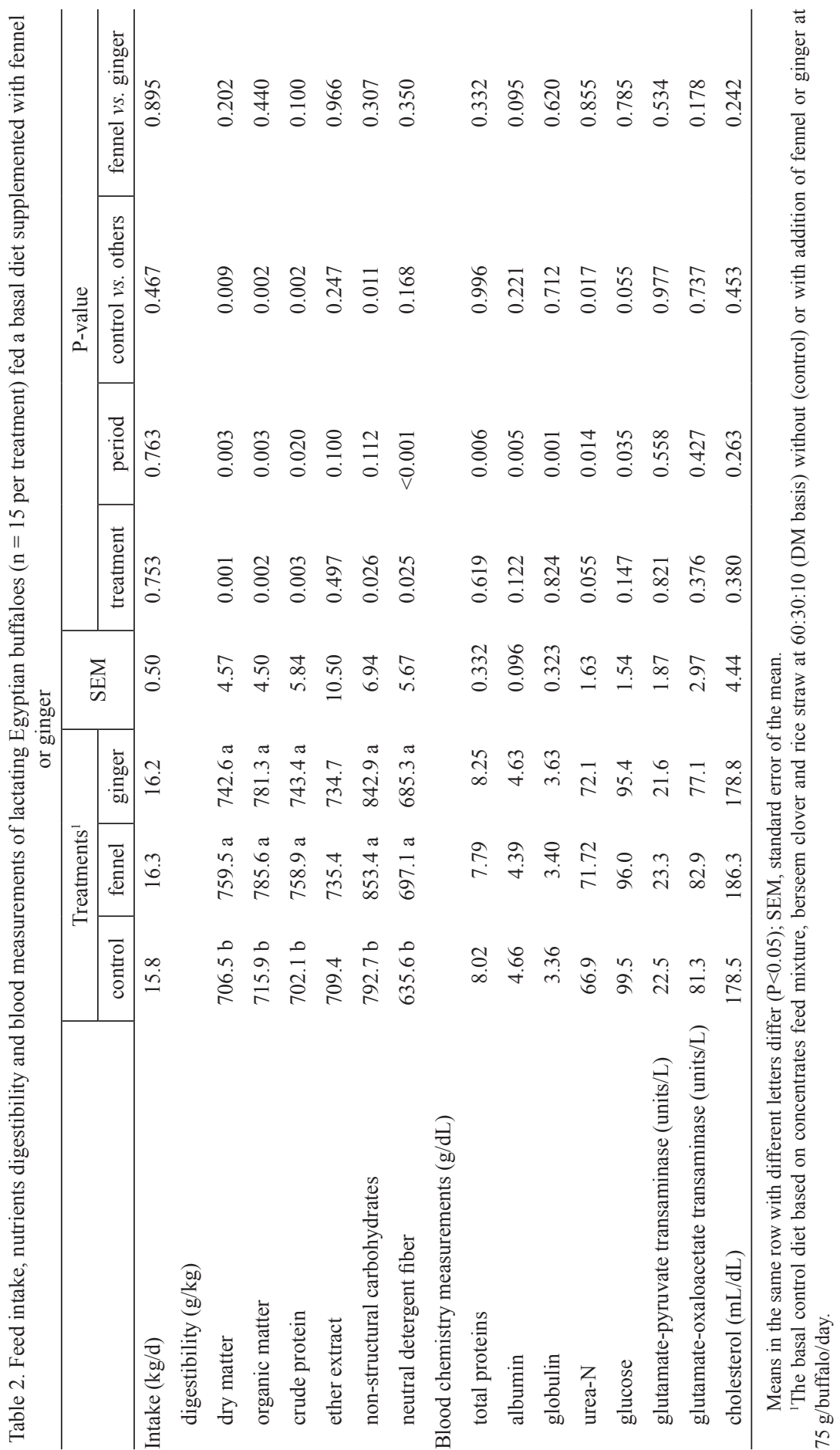




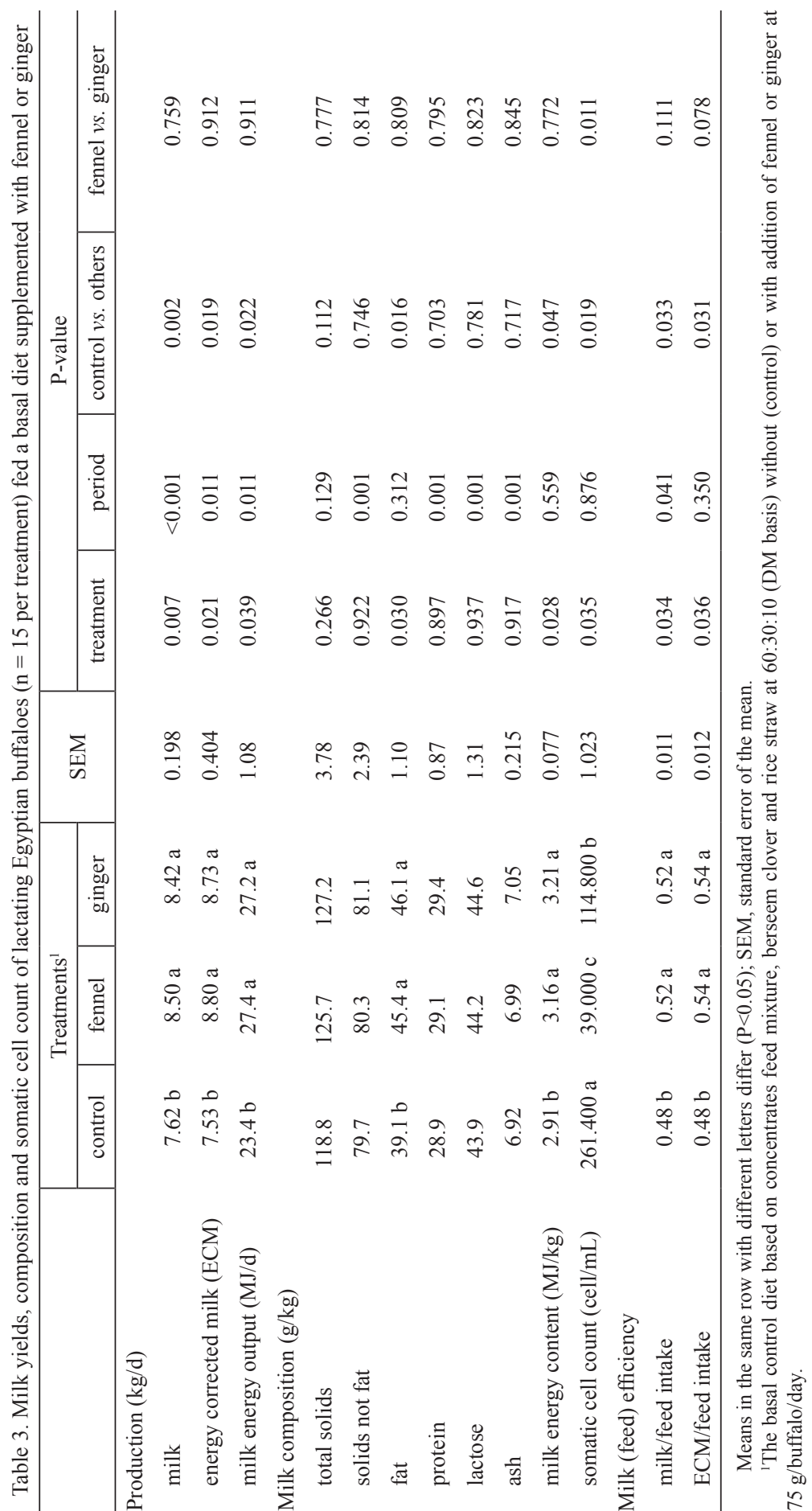




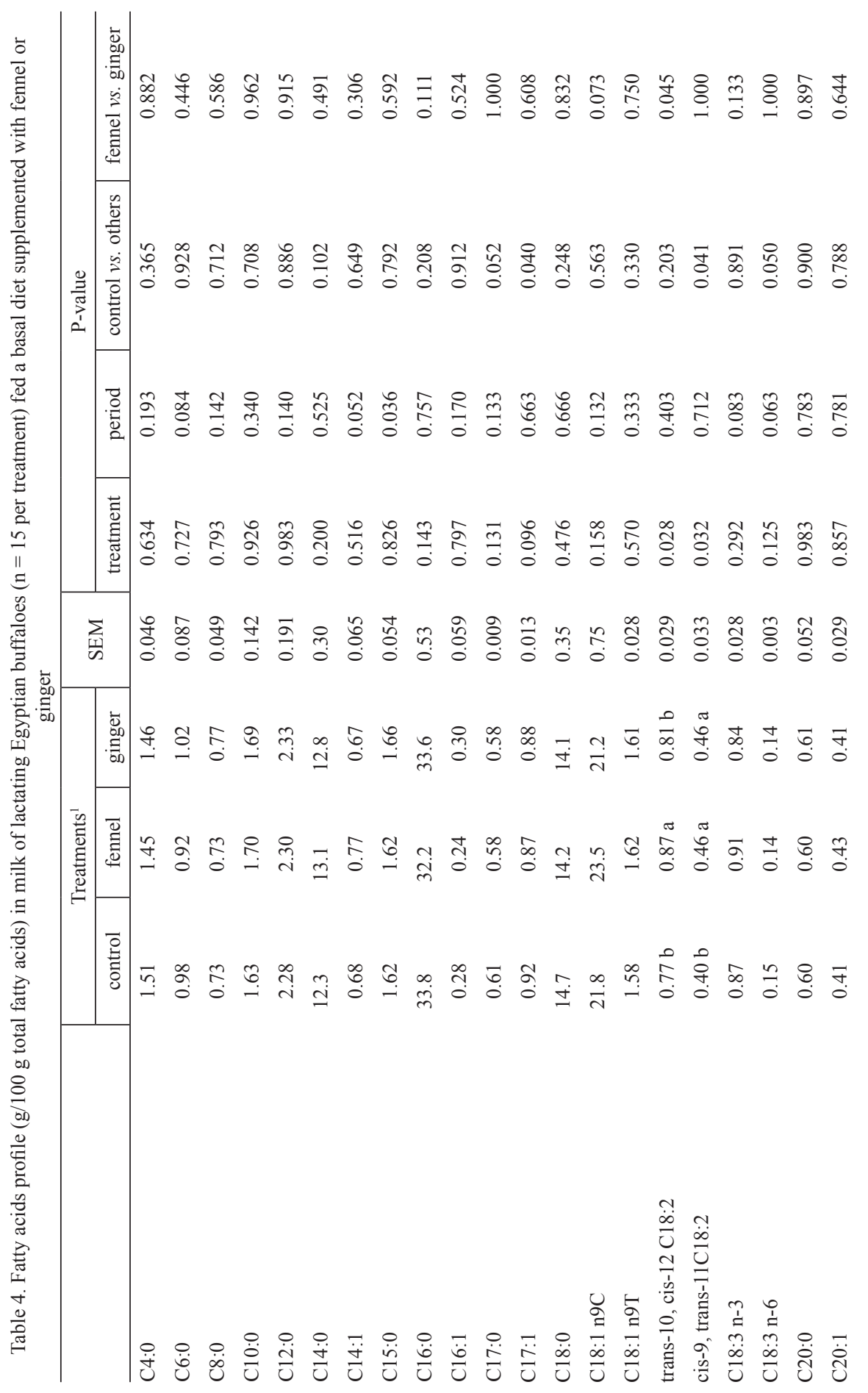




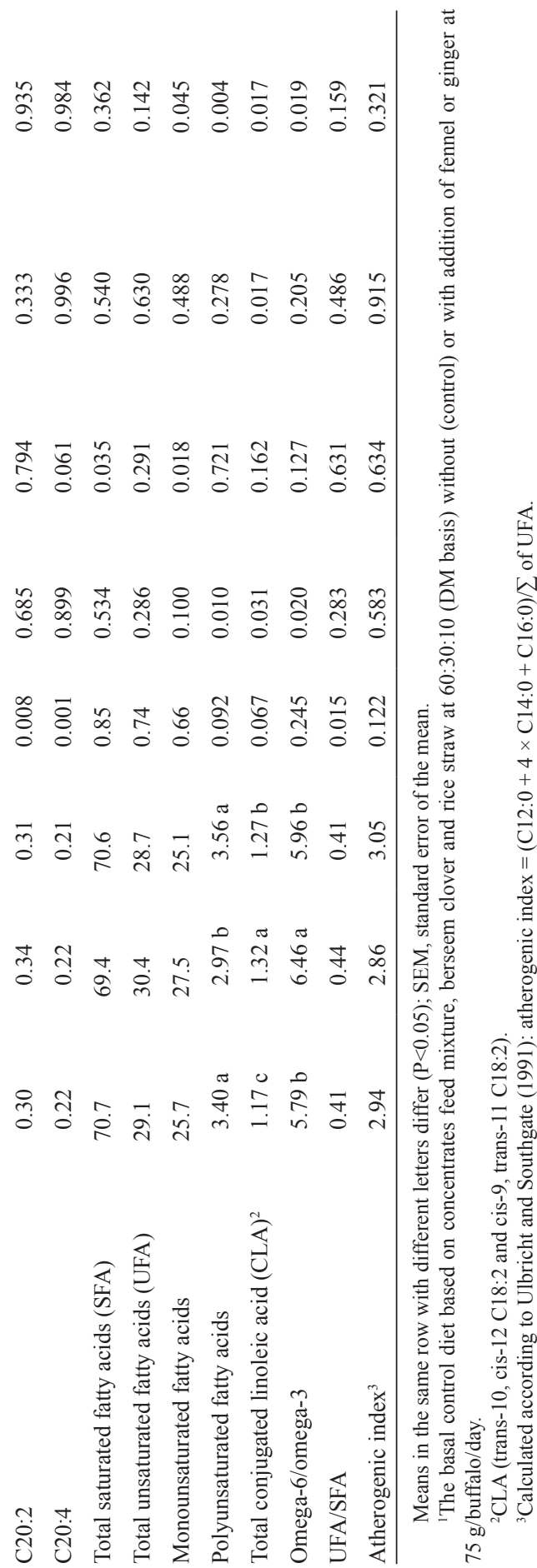




\section{Discussion}

\section{Feed intake, digestibility and blood measurements}

Fennel and ginger supplementation did not affect feed intake, revealing unaffected diet palatability with additives supplementation (Kholif et al., 2018 a). Hajalizadeh et al. (2019) observed improved diet palatability with fennel fed at $0.75 \%$ and $1.5 \%$ of diets for 80 days. Moheb et al. (2015) observed that feeding fennel byproduct did not affect feeding intake of growing Afshari $\times$ Chal male lambs. Differences may be related to the dose of additives, animal species, fed diets or physiological stage.

Fennel and ginger supplementation improved nutrient digestibility (DM by 5.7 and $5.1 \%$, OM by 9.7 and $9.1 \%$, NSC by 7.7 and $6.3 \%$, respectively). These results suggest that the used levels of additives were behind the level that causes some probable negative effects on ruminal microflora and fermentability (Zhang et al., 2011; Kholif et al., 2018 c). The negative effects may be due to inhibiting Gram-positive and Gram-negative bacteria, due to the active components in supplementations (Elghandour et al., 2015; Valdes et al., 2015). Ginger supplementation increases the secretion of saliva resulting in increased secretion and activity of digestion enzymes and finally increases the digestion processes (Ernst and Pittler, 2000). Srinivasan (2005) reported stimulated secretion of digestive enzymes with most of the herbal plants.

Fennel and ginger supplementation enhanced fiber digestibility (NDF by 9.7 and $7.8 \%$, respectively), which may be due to the ability of plant secondary metabolites to increase cellulolytic bacterial number (Giannenas et al., 2011; Ebeid et al., 2020 a). Fennel contains anethole, limonene, $\alpha$-pinene, fenchol, fenchone and estragole (Hajalizadeh et al., 2019), while ginger contains camphene, neral, $\beta$-bisabolene, ar-curcumene, $\beta$-eudesmol and other compounds that have antimicrobial activities against ruminal protozoa but without any negative effects on ruminal cellulolytic activity (Benchaar et al., 2008; Ebeid et al., 2020 b). Mahmoud et al. (2020) observed improved nutrient digestibility with fennel supplementation at $0.7 \%$ of diet of Holstein-Friesian $\times$ Black and White Lowland crossbred lactating cows for 90 days.

Result of blood parameters indicates that buffaloes in the present study were healthy, and that animals were not experiencing any stressful conditions (Rivero et al., 2016). Additives supplementation did not affect blood biochemistry. The minimal effects of fennel and ginger feeding on serum total protein, albumin, and urea-N indicate unaffected nutritional status of buffaloes, marginal protein catabolism, and healthy kidney conditions (Kholif et al., 2016). Additionally, these results indicate minimal effect on liver activity. Liver has important role in protein metabolism, and any deterioration in its cells will be reflected in the total serum proteins and levels of serum GOT and GPT (Mbuh and Mbwaye, 2005). The unaffected serum globulin level is an indicator of a stable immune response of the body.

The minimal effects on serum GOT and GPT indicate the health status of the livers and the absence of liver pathological lesions of the animals (Pettersson et al., 2008). However, treatments improved OM and NSC digestibility, concentrations of 
serum glucose were not affected. The minimal effect of treatment on feed intake may explain these results. The minimal effects on serum glucose indicate marginal body fat mobilization (McGuffey et al., 2001). Lakhani et al. (2019) evaluated the effect of supplementing growing buffalo calves (15-18 months of age) with phytogenics mixture containing fennel at 2 or $4 \%$ of feed intake for 120 days. They observed that fennel supplementation increased the concentrations of total protein, albumin, globulin, GOT and GPT and decreased cortisol and glucose without affecting the concentration of triglycerides, urea and alkaline phosphatase. Variations between experiments might be due to variations in experimental design, doses of additives, diets and animal physiological stage.

\section{Lactational performance}

Fennel and ginger improved production of milk by 10.5 and $11.6 \%$ and ECM by 16 and $16.8 \%$, respectively. Increasing milk production with supplementations, without affecting feed intake was reflected as improved feed efficiency by 8.3 and $12.5 \%$ for fennel and ginger treatments, respectively, compared with the control (Salem et al., 2014). Generally, the improved milk production is a direct result of the cumulative effects of improved nutrient digestion (Salem et al., 2014; Kholif et al., 2021 b). Ginger and fennel help to increase the absorption of essential nutrients, causing greater milk production (Belewu, 2006; Mahmoud et al., 2020). Moreover, ginger increases the stability of the gastrointestinal ecosystem through inhibition of pathogenic microorganisms growth (Belewu, 2006), resulting in improved milk production. Phytogenic supplementation improves feed utilization and absorption of nutrients, activates the immune system, and stimulates the endocrine system (Bhatt, 2015; Kholif et al., 2021 a). Al-Musodi and Jaafar (2019) observed greater milk production with ginger supplementation to lactating Iraqi goats for 5 months. Recently, Mahmoud et al. (2020) observed increased milk production with fennel supplementation to Holstein-Friesian $\times$ Black and White Lowland crossbred lactating cows at $0.7 \%$ of total DM of diet for 90 days.

Fennel and ginger increased milk fat concentration by 17.9 and $16.1 \%$, respectively. This result is in consistence with the observation of Mahmoud et al. (2020), who supplemented lactating cows with fennel at $0.7 \%$ of total diet for 90 days. However, we did not study ruminal fermentation, one can speculate that increasing milk fat is a result of increasing ruminal acetate (Kholif et al., 2018 b, 2019) with fennel and ginger supplementation. Experiments (Kholif et al., 2017 a; Morsy et al., 2018) showed increased ruminal acetate with herbs (lemongrass and rosemary) and plant seeds (mustard and cumin) supplementation to lactating Damascus goats at $10 \mathrm{~g} / \mathrm{goat}$ daily for 12 weeks.

The use of ethnoveterinary medicine with some herbals and phytogenic supplementations may present a cheaper and sustainable alternative to synthetic medicines (Dilshad et al., 2010; Kholif et al., 2018 b). Somatic cells in milk are a mixture of milk-producing cells and immune cells that are secreted in milk during the normal course of milking and are used as an index for estimating mammary health and milk quality of dairy animals (Alhussien and Dang, 2018). Low number of milk SCC indicates better milk products with a longer shelf life (Alhussien and Dang, 2018). 
In the present experiment, fennel followed by ginger decreased the SCC by 56 and $85 \%$, respectively, indicating reduced mammary inflammatory response and better milk quality compared to control group. Variations between fennel and ginger may attributed to the qualitative and quantitative differences in biochemical constituents of the plants (Dilshad et al., 2010). The concentrations of biochemical constituents like phenolics, polyphenols, terpenoids, essential oils, alkaloids, lectins and polypeptides differ between plants (Cowan, 1999).

Supplementations with fennel and ginger affected milk fatty acid profile. Mahmoud et al. (2020) observed altered milk fatty acid profile of lactating cows receiving fennel at $0.7 \%$ of total diet. They observed increased omega-3, PUFA, and CLA, while decreased saturated fatty acids (SFA) proportions. Fennel and ginger increased the proportions of cis-9, trans-11 C18:2 by 15\%. Moreover, fennel increased the proportion of trans- 10 , cis- $12 \mathrm{C} 18: 2$ by $12.3 \%$, and omega- $6 /$ omega- 3 ratio by $11.7 \%$. Milk fatty acid profile is very sensitive to dietary manipulation and feed supplementations (Kholif et al., 2017 b; Azzaz et al., 2020). Fennel and ginger contain bioactive constituents that may affect ruminal biohydrogenation of fatty acids (Jayanegara et al., 2012; Kholif et al., 2019). Moreover, fennel and ginger contain bioactive components with antimicrobial activities against some species of ruminal microbes. Helander et al. (1998) observed antibacterial activity with phytochemicals against Gram-positive bacteria, which participate in ruminal biohydrogenation process of the UFA in the rumen (Hobson and Stewart, 1997). Phytochemicals have the ability to decrease the number and the activity of ruminal microbes that are responsible about the biohydrogenation of dietary UFA, which cause increased UFA transformation from rumen to milk (Kim et al., 2016). In the present experiment, the proportions of total UFA were not affected; however, fennel increased monounsaturated fatty acids proportion.

Fennel and ginger increased proportions of CLA by 12.8 and $8.5 \%$, respectively, which is an important indicator of improved milk quality as a functional food for human consumers. Milk CLA plays a good role in decreasing the risk of cardiovascular disorders and possesses anticarcinogenic properties (Abedi and Sahari, 2014). Moreover, CLA plays an important role in the prevention of atherosclerosis, cancer and hypertension, and enhancing the immunity of human consumers (Bhattacharya et al., 2006). Increasing milk CLA is related to the sensitivity of ruminal Butyrivibrio fibrisolvens and Butyrivibrio proteoclasticum (the main ruminal bacteria responsible for the production of CLA before its transformation to the mammary glands) to phytochemicals (Buccioni et al., 2015; Wang and Lee, 2015). Milk CLA mainly originates from the ruminal biohydrogenation of $\mathrm{C} 18: 2$ and the endogenous synthesis from vaccenic acid through ruminal biohydrogenation via $\Delta^{9}$-desaturase in the mammary gland (Corl et al., 2001). Mahmoud et al. (2020) observed altered milk fatty acid profile of lactating cows receiving fennel for 90 days, including increased omega-3, PUFA, and CLA, and decreased SFA proportions.

\section{Conclusion}

Under the conditions of the present study, using of fennel or ginger at $75 \mathrm{~g}$ daily in the diet of lactating Egyptian buffaloes did not affect feed intake; however, im- 
proved nutrient digestibility. Supplementations improved milk production and milk fat content. Minimal differences were observed between fennel or ginger supplementation; therefore, both of them are recommended. Fennel improved the nutritive value of produced milk compared to ginger supplementation. Further investigations are necessary to explore other effects of different levels of fennel and ginger on ruminal fermentation, nutrient digestion and lactational performance, to confirm or deny the observed positive effects of fennel and ginger in the present experiment.

\section{References}

Abd El Tawab A.M., Kholif A.E., Khattab M.S.A., Shaaban M.M., Hadhoud F.I., M o s t a fa M.M.M., O l a fa d e h a n O.A. (2020). Feed utilization and lactational performance of Barki sheep fed diets containing thyme or celery. Small Rumin. Res., 192: 106249.

A bedi E., S ah ari M.A. (2014). Long-chain polyunsaturated fatty acid sources and evaluation of their nutritional and functional properties. Food Sci. Nutr., 2: 443-463.

A 1 - M u s o d i M.F., J a a far H.M. (2019). Effect of dietary Zingiber officinalis root powder and vitamin E-selenium on milk yield and its chemical composition in lactating Iraqi female goats. IOP Conf. Ser. Earth Environ. Sci., 388: 012022.

A 1 hus si en M.N., D ang A.K. (2018). Milk somatic cells, factors influencing their release, future prospects, and practical utility in dairy animals: An overview. Vet. World 11, 562-577.

AOAC (1997). Official Methods of Analysis, 16th ed. Association of Official Analytical Chemists, Washington, DC, USA.

Azzaz H.H., Kholif A.E., Abd El Tawab A.M., Khattab M.S.A., Murad H.A., Ola fa d e h a n O.A. (2020). A newly developed tannase enzyme from Aspergillus terreus versus commercial tannase in the diet of lactating Damascus goats fed diet containing pomegranate peel. Livest. Sci., 241: 104228 .

B e l e w u M.A. (2006). A functional approach to dairy science and technology, 1st ed. Adlek Printing Enterprises, Ilorin, Nigeria.

B enchaar C., Cals a miglia S., Chaves A.V., Fraser G.R., Colombatto D., Mc A 1 lis t e r T.A., B e a u c h e m in K.A. (2008). A review of plant-derived essential oils in ruminant nutrition and production. Anim. Feed Sci. Technol., 145: 209-228.

B h a t $\mathrm{N}$. (2015). Herbs and herbal supplements, a novel nutritional approach in animal nutrition. Iran. J. Appl. Anim. Sci., 5: 497-516.

Bhat tacharya A., Banu J., Rahman M., Causey J., Fernandes G. (2006). Biological effects of conjugated linoleic acids in health and disease. J. Nutr. Biochem., 17: 789-810.

Buccioni A., Pauselli M., Viti C., Minieri S., Pallara G., Roscini V., Rapaccini S., Marinucci M.T., Lupi P., Conte G., Mele M. (2015). Milk fatty acid composition, rumen microbial population, and animal performances in response to diets rich in linoleic acid supplemented with chestnut or quebracho tannins in dairy ewes. J. Dairy Sci., 98: 1145-1156.

Cedillo J., Kholif A.E., S a lem A.Z.M., Elghandour M.M.Y., Vázquez J.F., Alons o M.U., B a rbabos a A., Cha g o yán J.C.V., R e yna A.G. (2015). Oral administration of Sauce llorón extract to growing lambs to control gastrointestinal nematodes and Moniezia spp. Asian Pac. J. Trop. Med., 8: 520-525.

Corl B.A., B a u m gard L.H., Dw y er D.A., Gri in ari J.M., Phillips B.S., B a u man D.E. (2001). The role of $\Delta 9$-desaturase in the production of cis-9, trans-11 CLA. J. Nutr. Biochem., 12: 622-630.

C ow a n M.M. (1999). Plant products as antimicrobial agents. Clin. Microbiol. Rev., 12: 564-582.

Dhayalan M., Anitha Jegadeeshwari L., Nagendra Gandhi N. (2015). Biological activity sources from traditionally used tribe and herbal plants material. Asian J. Pharm. Clin. Res., 8: $11-23$.

D il sh a d S.M.R., Rehm a n N.U., A h m a d N., I q b a 1 A. (2010). Documentation of ethnoveterinary practices for mastitis in dairy animals in Pakistan. Pak. Vet. J., 30: 167-171. 
E b e i d H.M., K hol if A.E., Chren k o v a M., A n e le U.Y. (2020 a). Ruminal fermentation kinetics of Moringa oleifera leaf and seed as protein feeds in dairy cow diets: in sacco degradability and protein and fiber fractions assessed by the CNCPS method. Agrofor. Syst., 94: 905-915.

Eb e i d H.M., M engwe i L., Kholif A.E., Has s an F. ul, Liju a n P., Xin L., Chengjian Y. (2020 b). Moringa oleifera oil modulates rumen microflora to mediate in vitro fermentation kinetics and methanogenesis in total mix rations. Curr. Microbiol., 77: 1271-1282.

E 1 ghandour M.M.M.Y., Kholif A.E., B astida A.Z., Martínez D.L.P., S a lem A.Z.M. (2015). In vitro gas production of five rations of different maize silage and concentrate ratios influenced by increasing levels of chemically characterized extract of Salix babylonica. Turkish J. Vet. Anim. Sci., 39: 186-194.

Ernst E., P it t l e r M.H. (2000). Efficacy of ginger for nausea and vomiting: A systematic review of randomized clinical trials. Br. J. Anaesth., 84: 367-371.

Ferret A., P la ix ats J., Caja G., Gas a J., Prió P. (1999). Using markers to estimate apparent dry matter digestibility, faecal output and dry matter intake in dairy ewes fed Italian ryegrass hay or alfalfa hay. Small Rumin. Res., 33: 145-152.

G ha z y O.A., F o u a d M.T., S a l e h H.H., K h o 1 if A.E., M o r s y T.A. (2021). Ultrasound-assisted preparation of anise extract nanoemulsion and its bioactivity against different pathogenic bacteria. Food Chem., 341: 128259.

Giannenas I., Skoufos J., Giannakopoulos C., Wiemann M., Gortzi O., Lalas S., $\mathrm{K}$ y ri a z a k is I. (2011). Effects of essential oils on milk production, milk composition, and rumen microbiota in Chios dairy ewes. J. Dairy Sci., 94: 5569-5577.

Hajalizadeh Z., Dayani O., Khezri A., Tahmasbi R., Mohammadabadi M.R. (2019). The effect of adding fennel (Foeniculum vulgare) seed powder to the diet of fattening lambs on performance, carcass characteristics and liver enzymes. Small Rumin. Res., 175: 72-77.

Helander I.M., Alakomi H.-L.L., Latva-Kala K., Mattila-Sandholm T., Pol I., S mid E.J., Gorris L.G.M.M., von Wright A. (1998). Characterization of the action of selected essential oil components on gram-negative bacteria. J. Agric. Food Chem., 46: 3590-3595.

H o b s o n P.N., S t e w a r t C.S. (1997). The rumen microbial ecosystem. Springer Netherlands, Dordrecht. https://doi.org/10.1007/978-94-009-1453-7

J a y a n g ar a A., Kreuzer M., Le iber F. (2012). Ruminal disappearance of polyunsaturated fatty acids and appearance of biohydrogenation products when incubating linseed oil with alpine forage plant species in vitro. Livest. Sci., 147: 104-112.

Khattab M.S.A., Kholif A.E., Abd El Tawab A.M., Shaaban M.M., Hadhoud F.I., El-F o u ly H.A., O l a fa d e han O.A. (2020). Effect of replacement of antibiotics with thyme and celery seed mixture on the feed intake and digestion, ruminal fermentation, blood chemistry, and milk lactation of lactating Barki ewes. Food Funct., 11: 6889-6898.

Kholif A.E., Mors y T.A., Gouda G.A., An el e U.Y., G a l y e a n M.L. (2016). Effect of feeding diets with processed Moringa oleifera meal as protein source in lactating Anglo-Nubian goats. Anim. Feed Sci. Technol., 217: 45-55.

Kholif A.E., Matloup O.H., Morsy T.A., Abdo M.M., Abu Elella A.A., Anele U.Y., Sw a n s on K.C. (2017 a). Rosemary and lemongrass herbs as phytogenic feed additives to improve efficient feed utilization, manipulate rumen fermentation and elevate milk production of Damascus goats. Livest. Sci., 204: 39-46.

Khol if A.E., Mors y T.A., Matloup O.H., An ele U.Y., Moh a m ed A.G., E 1-S y e d A.B. (2017 b). Dietary Chlorella vulgaris microalgae improves feed utilization, milk production and concentrations of conjugated linoleic acids in the milk of Damascus goats. J. Agric. Sci., 155: 508-518.

Kholif A.E., Gouda G.A., An e le U.Y., Galye a n M.L. (2018 a). Extract of Moringa oleifera leaves improves feed utilization of lactating Nubian goats. Small Rumin. Res., 158: 69-75.

K hol if A.E., G o u d a G.A., O l a fa d e ha n O.A., A b d o M.M. (2018 b). Effects of replacement of Moringa oleifera for berseem clover in the diets of Nubian goats on feed utilisation, and milk yield, composition and fatty acid profile. Animal, 12: 964-972.

Khol if A.E., Kassab A.Y., Azzaz H.H., Matloup O.H., Hamdon H.A., Olafadeha n O.A., M o r s y T.A. (2018 c). Essential oils blend with a newly developed enzyme cocktail works synergistically to enhance feed utilization and milk production of Farafra ewes in the subtropics. Small Rumin. Res., 161: 43-50. 
Kholif A.E., Gou da G.A., Ga ly e a n M.L., A ne le U.Y., M or s y T.A. (2019). Extract of Moringa oleifera leaves increases milk production and enhances milk fatty acid profile of Nubian goats. Agrofor. Syst., 93: 1877-1886.

Kholif A.E., Hassan A.A., El Ashry G.M., Bakr M.H., E1-Zaiat H.M., Olafadehan O.A., Matloup O.H., S a 11 a m S.M.A. (2021 a). Phytogenic feed additives mixture enhances the lactational performance, feed utilization and ruminal fermentation of Friesian cows. Anim. Biotechnol., 32: 708-718.

K hol if A.E., H a s s a n A.A., M a 1 lou p O.H., El A s h r y G.M. (2021 b). Top-dressing of chelated phytogenic feed additives in the diet of lactating Friesian cows to enhance feed utilization and lactational performance. Ann. Anim. Sci., 21: 657-673.

K i m M.J., Jung U.S., J e on S.W., Le e J.S., K im W.S., L e e S.B., Kim Y.C., K im B.Y., Wang T., L e e H.G. (2016). Improvement of milk fatty acid composition for production of functional milk by dietary phytoncide oil extracted from discarded pine nut cones (Pinus koraiensis) in Holstein dairy cows. Asian-Australas. J. Anim. Sci., 29: 1734-1741.

Kooti W., Moradi M., Ali-Akbari S., Sharafi-Ahvazi N., Asadi-Samani M., A shtary-Larky D. (2015). Therapeutic and pharmacological potential of Foeniculum vulgare Mill: A review. J. Herb. Med. Pharmacol., 4: 1-9.

L a kh a $\mathrm{n}$ N., K a m r a D.N., L a kh a $\mathrm{n}$ i P., A 1 h u s s i e n M.N. (2019). Immune status and haematobiochemical profile of buffalo calves supplemented with phytogenic feed additives rich in tannins, saponins and essential oils. Trop. Anim. Health Prod., 51: 565-573.

Mahmoud A.E.M., Rahmy H.A.F., Ghoneem W.M.A. (2020). Role of caraway, fennel and melissa addition on productive performance of lactating Frisian cows. Pakistan J. Biol. Sci., 23: $1380-1389$.

Matloup O.H., Abd El Tawab A.M., Hass an A.A., Hadhoud F.I., Khattab M.S.A., K ha 1 e 1 M.S., S a 11 a m S.M.A., K h o 1 if A.E. (2017). Performance of lactating Friesian cows fed a diet supplemented with coriander oil: Feed intake, nutrient digestibility, ruminal fermentation, blood chemistry, and milk production. Anim. Feed Sci. Technol., 226: 88-97.

M bu h J.V., M b w a y e J. (2005). Serological changes in goats experimentally infected with Fasciola gigantica in Buea sub-division of S.W.P. Cameroon. Vet. Parasitol., 131: 255-259.

M c Guffe y R.K., R i c h a rd s o n L.F., Wi 1 k in s o n J.I.D. (2001). Ionophores for dairy cattle: current status and future outlook. J. Dairy Sci., 84: E194-E203.

Moheb S.Z., Fatahnia F., Alipour D. (2015). Effect of fennel by-product on performance of growing lambs and gas production parameters of their diets. Iran. J. Anim. Sci., 46: Pe201-Pe210.

Morsy T.A., Kholif A.E., Matloup O.H., Elella A.A., Anele U.Y., Caton J.S. (2018). Mustard and cumin seeds improve feed utilisation, milk production and milk fatty acids of Damascus goats. J. Dairy Res., 85: 142-151.

NRC (2001). Nutrient Requirements of Dairy Cattle, 7th ed. National Academies Press, D.C., USA.

Pet ters son J., Hind orf U., P ers s on P., B eng t s s on T., M a l m qvis t U., Werkströ m V., Ekelund M. (2008). Muscular exercise can cause highly pathological liver function tests in healthy men. Br. J. Clin. Pharmacol., 65: 253-259.

Rivero N., S a lem A.Z.M., Ayala M., Elghandour M.M.Y., Kholif A.E., B a rbabos a A., C a m a cho L.M., R oj a s., Jolivares Ciprian o M. (2016). Influence of Salix babylonica extract, exogenous enzyme of xylanase and their combination on blood haematological and biochemical profile in sheep and goats. Indian J. Anim. Sci., 86: 1140-1144.

S a e edi S., Dayani O., Tahmasbi R., Khezri A. (2017). Effect of supplementation of calf starter with fennel powder on performance, weaning age and fermentation characteristics in Holstein dairy calves. J. Anim. Physiol. Anim. Nutr. (Berl), 101: 81-87.

S a le m A.Z.M., K holif A.E., E $1 \mathrm{~g} h$ and our M.M.Y., B u endía G., Mari e z c urrena M.D., $\mathrm{H}$ e r $\mathrm{n}$ a $\mathrm{n}$ de z S.R., C a m a c h o L.M. (2014). Influence of oral administration of Salix babylonica extract on milk production and composition in dairy cows. Ital. J. Anim. Sci., 13: 10-14.

S a le m A.Z.M., Elghandour M.M.Y., Khol if A.E., López S., Pli e go A.B., Cipriano- S a lazar M., Chagoyán J.C.V., de O c a Jiménez R.M., A lonso M.U. (2017). Tree leaves of Salix babylonica extract as a natural anthelmintic for small-ruminant farms in a semiarid region in Mexico. Agrofor. Syst., 91: 111-122. 
S j a un j a L.O., B a evre L., Ju nk karine n L., P ed er se n J., S e ta l a J. (1991). A Nordic proposal for an energy corrected milk (ECM) formula. EAAP Publ., 50: 156-157.

S r in iv a s a n K. (2005). Spices as influencers of body metabolism: An overview of three decades of research. Food Res. Int., 38: 77-86.

Tyrrell H.F., Reid J.T. (1965). Prediction of the energy value of cow's milk. J. Dairy Sci., 48: $1215-1223$.

U 1 b r i c h t T.L.V., S o u th g a t e D.A.T. (1991). Coronary heart disease: seven dietary factors. Lancet, 338: 985-992.

Vald e s K.I., S a le m A.Z.M., L o p e z S., A 1 o n s o M.U., R ive ro N., E $1 \mathrm{~g} h$ a nd o u r M.M.Y., D o míng u e z I.A., R on quillo M.G., K hol if A.E. (2015). Influence of exogenous enzymes in presence of Salix babylonica extract on digestibility, microbial protein synthesis and performance of lambs fed maize silage. J. Agric. Sci., 153: 732-742.

Van Soest P.J., Roberts on J.B., Lew is B.A. (1991). Methods for dietary fiber, neutral detergent fiber, and nonstarch polysaccharides in relation to animal nutrition. J. Dairy Sci., 74: $3583-3597$.

W a n g T., L e e H.G. (2015). Advances in research on cis-9, trans-11 conjugated linoleic acid: a major functional conjugated linoleic acid isomer. Crit. Rev. Food Sci. Nutr., 55: 720-731.

Zhang T.T., Yang Z.B., Yang W.R., Jiang S.Z., Zhang G.G. (2011). Effects of dose and adaptation time of ginger root (Zingiber officinale) on rumen fermentation. J. Anim. Feed Sci., 20: $461-471$.

Received: 19 XI 2020

Accepted: 20 I 2021 